УДК: $378.147 .091 .31-059.2$

DOI:

Інна Шоробура, доктор педагогічних наук, професор,

ректор Хмельницької гуманітарно-педагогічної академії

Юляна Ткаченко, аспірант Хмельницької гуманітарно-педагогічної академї

\title{
ТРЕНІНГОВІ ТЕХНОЛОГІЇ У ЗАКЛАДАХ ВИЩОЇ ОСВІТИ
}

У статті розкрито сутність тренінгових технологій, їх ефективність у використанні в закладах вищої освіти. Звернено увагу на види тренінгу, зокрема соиіально-психологічний, особистісного зростання, тематичний, комунікативний, психокорекційний, психотерапевтичний та ін. Акцентовано на структурі тренінгу: вступна частина, основна, заключна, розкрито їх зміст. Відмічено, що основними складовими тренінгу є: тренінгова група, коло, приладдя для тренінгу, тренер, правила групи, інтерактивні методи навчання, оцінювання ефективності тренінгу та ін. Також визначено принципи організації тренінгу, зокрема мотиваційність, парадоксальність, образність, спрямованість на застосування результатів та ін.

Ключові слова: тренінгові технологї; заклади вищої освіти; види тренінгу; структура тренінгу; принципи організації тренінгу.

Jim. 5.

Inna Shorobura, Doctor of Sciences (Pedagogy), Professor, Rector of Khmelnytskiy Humanitarian Pedagogical Academy

Yulyana Tkachenko, Postgraduate Student, Khmelnytskiy Humanitarian Pedagogical Academy

\section{THE TRAINING TECHNOLOGIES IN HIGHER EDUCATION INSTITUTIONS}

The essence of training technologies, their effectiveness of use in higher education institutions has been disclosed in the article. The attention is paid to the types of training, in particular, socio-psychological, personal growth, thematic, communicative, psycho-corrective, psychotherapeutic, etc. The emphasis is on the structure of the training: the introductory part, the main, the final, and their content has been revealed. It is noted that the main components of the training are: a training group, a circle, training equipment, a coach, group rules, interactive methods of teaching, evaluation of training effectiveness, etc. Also, the principles of organization of training, in particular motivation, paradox, imagery, focus on the application of results, etc. have been defined. The high efficiency of training education is the result of the valuable position and knowledge of each participant; one can share their experience and analyze it in a comfortable atmosphere without coercion; it is possible to learn by doing practical actions; errors can be assumed that will not lead to punishment or negative consequences; there are no tools for evaluating new knowledge.

By using training technologies, the trainer first of all contributes to the reflection of the participants of the training of the knowledge acquired, which should be transformed through the intellect, experience, emotional experience of the subject of the activity, which to a large extent provides adequate feedback. During the training participants, due to feedback, identify the lack of skills, abilities and theoretical knowledge, as well as the inadequacy of existing settings and stereotypes. This helps to correct ineffective behavioral patterns and replace them with the new, more effective ones.

The significant advantage of training technology is that it provides a unique opportunity to study the complex, emotionally significant issues in the safe environment of training, but not in real life with its threats and risks. The training allows learning without worrying about the unpleasant consequences that may result if somebody makes wrong decision.

Keywords: training technologies; higher education institutions; types of training; a structure of training; principles of training organization.

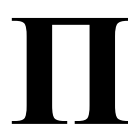
остановка проблеми у загальному вигляді. В Україні продовжується процес реформування національної системи вищої освіти, пов'язаний з її інтеграцією в єдиний загальноєвропейський освітній простір. В Законі України “Про вищу освіту” відмічено, що сучасна освіта передбачає відкритість майбутньому, а їі подальший розвиток повинен спрямовуватися на подолання замкненості й надання освітньому процесу творчого характеру, що потребує нової освітньої моделі, яка б відповідала реаліям постіндустріального суспільства, тим глобальним змінам в усіх сферах життя, які викликані сучасними інформаційнокомунікаційними технологіями, стрімкими інтеграційними процесами в світі. Саме тому важливого значення для розвитку суспільства набуває осмислення якісно нових ознак і смислів сучасної освіти в умовах євроінтеграції [1].

Тренінг виник у XIX ст. в медицині як методика 
проведення психотерапевтичної діяльності. У XX ст. він набуває поширення в професійній освіті як форма навчання, та в практичній психології як ефективна технологія розвитку особистості. Останнім часом тренінгові технології впроваджуються в процес навчання у закладах вищої освіти і певні їх елементи з'являються на уроках в загальноосвітніх школах. Особливо активно тренінгові методики використовуються в тих випадках, коли процес навчання спрямований не на накопичення наукової інформації, а на формування життєвих навичок i компетенцій. Тому саме тренінгові технології мають бути основою вивчення основ здоров'я, валеології, безпеки життєдіяльності, психології та ін.

Висока ефективність тренінгового навчання $\epsilon$ результатом того, що цінується позиція й знання кожного учасника; можна поділитися своїм досвідом і проаналізувати його у комфортній атмосфері без примусу; є можливість вчитися, виконуючи практичні дії; можна припускатися помилок, що не призводитиме до покарання або негативних наслідків; відсутні засоби оцінювання нових знань.

Використовуючи тренінгові технології, тренер насамперед сприяє рефлексії учасниками тренінгу отриманих знань, які мають трансформуватися через інтелект, досвід, емоційні переживання суб'єкта діяльності, що значною мірою забезпечує адекватний зворотний зв'язок. У процесі тренінгу учасники, завдяки зворотному зв'язку, виявляють брак умінь, навичок та теоретичних знань, а також неадекватність наявних установок і стереотипів. Це сприяє корекції неефективних моделей поведінки та їх заміні на нові, більш ефективні [4].

Суттєвою перевагою тренінгових технологій $\epsilon$ те, що вона дає унікальну можливість вивчити складні, емоційно значимі питання в безпечній обстановці тренінгу, а не в реальному житті з його загрозами та ризиками. Тренінг дає змогу вчитися без хвилювання стосовно неприємних наслідків, які можуть виникнути у випадку прийняття неправильного рішення.

Аналіз останніх досліджень і публікацій. У рамках філософського осмислення розвиток сучасної освіти досліджували такі вчені, як В.П. Андрущенко, Л.В. Губерський, В.Г. Кремень, В.С. Лутай, В.О. Огнев'юк та ін. Проблемі розвитку вищої освіти України в контексті європейських інтеграційних процесів присвячені праці В.Г. Вікторова, О.А. Дубасенюк, М.Ф. Степко, Л.А. Овсянкіної, А.В. Шаповалова та ін. Інноваційні аспекти у вищій освіті розглядаються у працях І.Д. Беха, І.М. Дичківської, О.Я. Савченко, О.С. Падалки, О.М. Пехоти та ін.
Останнім часом у різних сферах i, зокрема, у навчанні широко досліджуються тренінги життєвих компетенцій, які з'явилися в 60 -ті роки і грунтуються на ідеях гуманістичної психології К. Роджерса. Відповідно до концепції цих тренінгів припускається, що індивід недостатньо володіє уміннями, необхідними для ефективного міжособистісного функціонування. Науковці B.I. Свдокимов, В.А. Семиченко та ін. вважають, що форми і методи, які використовуються під час проведення тренінгів, грунтуються на активності кожного учасника освітнього процесу, на співіснуванні різних поглядів та вільному їх обговоренні. Одним із принципів організації тематичного або соціально-просвітницького тренінгу, на думку С.В. Страшка, Л.А. Животовської, $\epsilon$ партисипаторний підхід, який базується на вірі в те, що люди ефективніше вчаться, коли цінуються їхні власні знання та спроможність щось зробити, а також, коли вони здатні проаналізувати власний досвід та поділитися ним у комфортній обстановці [3].

Формулювання цілей статті. Мета статті - розкрити особливості тренінгових технологій у закладах вищої освіти, показати їх види, зміст, принципи організації.

Виклад основного матеріалу. Слово “тренінг” походить від англійського “to train”, що означає “навчати, тренувати, дресирувати”. Тренінг - це одночасно цікавий процес пізнання себе та інших; спілкування; ефективна форма опанування знань; інструмент для формування умінь і навичок; форма розширення досвіду.

Під час тренінгу створюється неформальне, невимушене спілкування, яке відкриває перед групою безліч варіантів розвитку та розв'язання проблеми, заради якої вона зібралася. Як правило, учасники в захваті від тренінгових методів, тому що ці методи роблять процес навчання цікавим, не обтяжливим.

Тренінг - це організаційна форма навчальновиховного процесу, яка, спираючись на досвід і знання ¥ї учасників, забезпечує ефективне використання різних педагогічних методів за рахунок створення позитивної емоційної атмосфери та спрямовується на отримання сформованих навичок і життєвих компетенцій.

Тренінг і традиційні форми навчання мають суттєві відмінності. Традиційне навчання більш орієнтоване на правильну відповідь, і за своєю суттю $€$ формою передачі інформації та засвоєння знань. Натомість тренінг, перш за все, орієнтований на запитання та пошук. На відміну від традиційних тренінгові технології повністю охоплюють весь потенціал людини: рівень та 


\section{ТРЕНІНГОВІ ТЕХНОЛОГІЇ У ЗАКЛАДАХ ВИЩОЇ ОСВІТИ}

обсяг іiі компетентності (соціальної, емоційної та інтелектуальної), самостійність, здатність до прийняття рішень, до взаємодії тощо. Звичайно, традиційна форма передачі знань не є сама по собі чимось негативним, проте у світі швидких змін і безперервного старіння знань традиційна форма навчання має звужені рамки застосування [4].

Так само, як і будь-яке навчальне заняття, тренінг має певну мету. Нею можуть бути: інформування та набуття учасниками тренінгу нових професійних навичок та умінь; опанування нових технологій у професійній сфері; зменшення небажаних проявів поведінки, стилю неефективного спілкування, особливостей реагування тощо; зміна погляду на проблему та на процес навчання; підвищення здатності учасників до позитивного ставлення до себе та життя; пошук ефективних шляхів розв'язання поставлених проблем завдяки об'єднанню в тренінговій роботі різних спеціалістів, представників різних відомств, які впливають на розв'язання цих проблем.

Мета будь-якого тренінгу полягає не в аналізі та інтерпретації проблем особистості, задля подальшого їх усунення або зміни мотивації поведінки, а в активному, свідомому виробленні бажаної поведінки [2].

Залежно від мети та завдань, які має вирішувати тренінг, можна виділити такі його види:

1. Соціально-психологічний тренінг спрямовується на розвиток комунікативних здібностей, міжособистісних відносин, уміння встановлювати та розвивати різні види стосунків між людьми;

2. Тренінг особистісного зростання спрямовується на самовдосконалення, вирішення внутрішньо особистісних конфліктів, суперечностей тощо;

3. Тематичний спрямовується на розгляд конкретної теми, зміст якої потрібно засвоїти.

4. Комунікативний - набуття навичок спілкування;

5. Тренінг прийняття рішень - для цього тренер може використовувати: “мозкові штурми”; обговорення однієї проблеми всією групою; ігри, спрямовані на усвідомлення та вирішення проблеми; алгоритм прийняття рішення тощо;

6. Стратегічний тренінг - допомагає педагогу гнучко реагувати в будь-якій ситуації, краще пристосовуватися до оточення, швидше знаходити вихід зі складних ситуацій, реалізовувати свої плани і досягати мети;

7. Психокорекційний тренінг - спрямовується на корекцію психічних процесів, тренування певних якостей і здібностей особистості [5].
Тренінг має свої “складові”. До них належать: тренінгова група; тренінгове коло; спеціально обладнане приміщення та приладдя для тренінгу (фліпчарт, маркери тощо); тренер; правила групи; атмосфера взаємодії та спілкування; інтерактивні методи навчання; структура тренінгового заняття; оцінювання ефективності тренінгу.

Тренінгова група - це спеціально створена група, учасники якої за сприяння ведучого (тренера) включаються в інтенсивне спілкування, спрямоване на досягнення визначеної мети та вирішення поставлених завдань. Тренінгова група зазвичай включає 15 - 20 осіб. Така кількість людей дозволяє оптимально використати час та ефективно навчати людей.

Тренінгові заняття можуть бути різної тривалості: від 1,5 - 3-х годин (2 - 4 академічні години тривалістю 45 хвилин кожна) до декількох днів поспіль. За тривалістю найбільш вдалою формою групової роботи є марафон, тобто проведення занять тривалістю $6-8$ годин щоденно протягом кількох днів. За такої форми роботи передбачається велика обідня перерва (не менше години) та дві перерви по 15 - 20 хвилин через кожні 1,5 - 2 години роботи.

Робочі місця для учасників у приміщенні можуть буги розташовані по-різному, але доцільно уникати “аудиторного" та "шкільного" стилів. Добре, коли стільці для учасників розташовуються півколом - це сприяє створенню неформальної атмосфери, забезпечує можливість кожному бачити всіх учасників тренінгу, підкреслює рівнозначність позицій усіх учасників. Це сприяє створенню атмосфери відкритості, розвитку довіри, уваги та інтересу учасників одного до одного.

Головне, що забезпечує сприятливу атмосферу для навчання у тренінговій групі, - це правила, яких має дотримуватися кожний учасник. Основні 3 них: цінування часу; увічливість; позитивність; розмова від свого імені; добровільна активність; конфіденційність; зворотний зв'язок тощо [4].

Правила приймаються на початку тренінгу всіма учасниками групи і потрібні для того, щоб кожний міг працювати в комфортних умовах; отримувати інформацію самому у зручний для кожного спосіб; відверто, без побоювань висловлювати свої думки. Також учасники тренінгу можуть дозволити собі спонтанні, попередньо не зважені вислови; бути впевненим, що надану ним інформацію використають тільки в інтересах учасників.

Тренінг проводить тренер (ведучий), котрий спілкується з учасниками "на рівних", є таким самим учасником тренінгової групи, як і всі інші 


\section{ТРЕНІНГОВІ ТЕХНОЛОГЇ У ЗАКЛАДАХ ВИЩОЇ ОСВІТИ}

учасники. Але одночасно він є й каталізатором усіх процесів, що відбуваються в групі на шляху до досягнення визначеної мети тренінгу (для цього він повинен розуміти настрій кожного учасника).

Тренер відрізняється від інших учасників тим, що володіє інформацією щодо означеної теми; знає методику проведення тренінгових занять; володіє навичками ведення тренінгової групи; знає методи оцінювання результатів тренінгу та вміє їх застосовувати.

У тренінгу широко використовуються методи, спрямовані на стимуляцію взаємодії учасників. Усі вони об'єднуються під назвою “інтерактивні техніки” і забезпечують взаємодію та власну активність учасників під час динамічного навчального процесу [2].

Проведення тренінгу відбувається за певною структурою. Типова структура, мета та завдання тренінгу разом слугують основою для складання плану його проведення. Такий план може мати різні форми: таблиця, перелік послідовних дій, схема тощо. План допоможе тренеру дотримуватися основних питань, які мають бути опрацьовані в ході роботи групи, інакше неможливо досягти поставленої мети тренінгу.

Будь-який тренінг складається 3 одних і тих самих частин: вступної, основної та заключної. Співвідношення за обсягом цих частин у кожному окремому випадку може бути різним. Це залежить від: цілей тренінгу; виду цільової групи; тривалості тренінгу; рівня підготовленості групи.

Мета вступної частини тренінгу - створення позитивної атмосфери в групі, прийняття правил, за якими будуть працювати учасники, та інформування їх стосовно мети, завдань і кінцевих результатів тренінгу.

У вступі необхідно ознайомити учасників 3 назвою тренінгу, яка має відповідати тим навичкам, виробленню яких він присвячений, або тій інформації, яка буде вивчатися. На наступному етапі формулюються завдання тренінгу, що забезпечує цілеспрямоване знайомство 3 матеріалом. Завдання мають враховувати індивідуальні інтереси учасників. Тренер обов'язково висвітлює актуальність проблеми 3 метою пробудити в учасників зацікавленість, що забезпечує ефективність навчання [4].

Зробити це тренер може за допомогою таких традиційних методів навчання як розповідь, лекція, бесіда та ін.

Розповідь - передбачає усний живий, послідовний виклад фактичного матеріалу в пояснювальній або оповідальній формі. Повинна мати пізнавальну або виховну спрямованість та наукову обгрунтованість фактів стосовно тематики тренінгу, чітку логіку та образність й емоційнузабарвленість. Лекція - відрізняється від розповіді тим, що використовується для розгорнутого теоретичного повідомлення, наукового аналізу та обгрунтування складних наукових проблем. Бесіда - метод словесного обговорення матеріалу, що вивчається. Його завдання полягає в тому, щоб, по-перше, за допомогою цілеспрямованих і вміло поставлених запитань актуалізувати відомі учасникам знання; по-друге, досягти засвоєння ними нових знань шляхом самостійних обмірковувань, узагальнень та інших розумових операцій. Як правило на початку тренінгу, з метою з'ясування готовності учасників до певних навчально-пізнавальних дій, використовують вступну бесіду або бесідуповідомлення, яка базується на спостереженнях, певних документах тощо. Результативність бесіди безпосередньо залежить від уміння педагога правильно сформулювати запитання.

Також у вступі визначається тематика тренінгу, час його проведения тощо. У разі, коли тренінг проводиться в рамках навчального процесу у закладі вищої освіти, оптимальний час для нього має становити чотири академічні години.

Наступним кроком може бути знайомство (вітання) учасників тренінгу. Враховуючи те, що при проведенні тренінгів у вишах учасники знають один одного, то знайомство може відбутися у вигляді психогімнастичної вправи, спрямованої на створення невимушеної, дружньої, привітної атмосфери в групі з відчуттям взаємної симпатії [2].

Завдання знайомства полягає у тому, щоб допомогти учасникам тренінгу уявити себе в безпечному середовищі; дати можливість поліпшити стосунки в групі; дозволити учасникам побачити усі свої сильні сторони й можливості і цим допомогти їм здобути навички позитивної самооцінки; дозволити побачити можливості власного зростання і впевнитись у тому, що всі учасники мають багато спільного, хоча i відрізняються один від одного; допомогти зрозуміти, що поруч присутні люди, на яких можна покластися.

Важливе значення має прийняття правил робити групи. Для результативності й ефективності тренінгу необхідно не тільки створити атмосферу відкритості та привітності 3 відчуттям взаємної поваги та симпатії, а й спробувати досягти обстановки дружнього співробітництва за обов'язкової умови свідомого виконання учасниками певних правил, зрозумілих i добровільно прийнятих кожним із них, які 


\section{ТРЕНІНГОВІ ТЕХНОЛОГІЇ У ЗАКЛАДАХ ВИЩОЇ ОСВІТИ}

допомагатимуть створити атмосферу довіри і підтримки, де кожен учасник може виражати свої почуття, висловлювати власні думки без побоювань; формувати навички спілкування, обговорення, вирішення проблеми, участі у спільному відпрацюванні рішень, бути здатним дивитися на ситуацію з погляду іншої людини. Зробити це можна, використовуючи такі вправи: “Сонечко", "Квітки”, "Параграф" та ін.

Правила мають бути розміщені на видному місці протягом всього тренінгу. Цим правилам повинні в подальшому слідувати усі. Згода щодо правил - важливий етап групової роботи. Побудова взаємовідносин у групі на основі

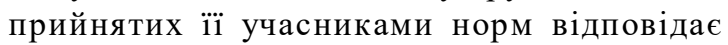
демократичним нормам. Крім цього, сам процес досягнення згоди може демонструвати якісно інший стиль взаємодії, оснований на повазі думки, поглядів і потреб кожного з учасників. Необхідно намагатися дотримуватися теми; поважати погляди один одного: не перебивати, не критикувати виступи; не оцінювати і не засуджувати будь-чиї вислови; висловлюватись від власного “Я”; не давати поради, якщо їх не просять; при аналізі ситуацій 3 життя використовувати придумані імена і змінювати деталі; дотримуватися регламенту часу; питання задавати в заключній частині тренінгу [4].

Після привітання, оголошення мети тренінгу й прийняття правил доцільно звернутися до учасників з проханням висловити свої очікування. Висловлюватись можна усно методом “мозкового штурму", або використовуючи вправу "Наші сподівання”, яка дає можливість учасникам зрозуміти і сформулювати результати, яких вони досягнуть, взявши участь у тренінгу. Поінформованість про результати навчання допомагає учасникам тренінгу перебороти недовіру і створює високу мотивацію.

В основній частині тренер повинен мати всі необхідні матеріали для проведення тематичного тренінгу. Він повинен відчувати себе компетентним і впевненим у ролі ведучого. 3 наявної інформації необхідно вибрати основну, що відповідає кінцевій меті тренінгу, і забезпечити постійне звертання учасників до цієї інформації впродовж усього проведення. Необхідно розподілити інформацію на 3 групи: 1) питання, які учасники повинні знати - це завдання, які потребують вирішення для досягнення мети тренінгу; 2) питання, які учасникам потрібно знати, - інформацію, яку слід детально обговорити; 3 ) питання, які учасники можуть знати, - інформацію, яку слід дати для самостійного ознайомлення після проведення окремої вправи, у вигляді дидактичного матеріалу. Відповідно до завдань тренінгу необхідно чітко розподілити час на кожне питання, щоб повністю розкрити їх.

Необхідно організувати весь матеріал у логічну послідовність, щоб вкластися у відведений час. Логіка викладення матеріалу має відповідати принципам навчання. Нова інформація має утворювати смислові асоціації зі знаннями, засвоєними учасниками раніше, та ускладнюватися поступово - від простого до складного, від відомого до невідомого, від близького до далекого, від легкого до важкого, від конкретного до абстрактного. Під час розкриття питань необхідно використовувати різні методи навчання, віддаючи перевагу методам активізації навчально-пізнавальної діяльності. Це, зокрема, інтелектуальна розминка. Проводиться протягом 10 - 15 хвилин у швидкому темпі у формі експрес-опитування: тренер звертається до учасників із запитаннями, на які вони повинні дати коротку, але конкретну і змістовну відповідь. Дидактична цінність методу полягає в тому, що він дає змогу швидко озвучити значний обсяг інформації, допомагає актуалізувати знання учасників і формує інтерес до подальшої роботи [3].

Можна використовувати метод сократичної бесіди, який спрямовується на формування вмінь творчо мислити, дає змогу виявити певні прогалини в знаннях учасників, підвищує інтерес до професійної діяльності чи певного навчального предмета, сприяє активному набуттю знань, формує навички творчого мислення і самостійної роботи, розвиває критичне мислення та вміння аргументовано відстоювати власну думку, вчить полемізувати. Сократична бесіда здійснюється шляхом постановки тренером перед учасниками тренінгу певних запитань у чіткій логічній послідовності так, що вони повинні давати не готові відповіді, а аналізувати певні факти й явища та водночас висловлювати власні погляди.

Актуалізація проблеми необхідна для того, щоб збуджувати в учасників інтерес до проблеми, яка розглядається, формувати у них мотивацію до зміни поведінки, а також для того, щоб вони усвідомили всю значимість цієї проблеми. Основне завдання цього етапу - зробити проблематику тренінгу актуальною для кожного 3 учасників. Етап можна провести за допомогою лекції.

Найбільш поширеною й порівняно простою формою активного залучення учасників тренінгу до навчального процесу є лекція-бесіда 3 використанням несподіваних запитань до 
аудиторії. Запитання мають інформаційний характер і спрямовуються на 3'ясування думок і рівня поінформованості учасників з проблеми, що вивчається, на актуалізацію знань, необхідних для iï розуміння, та визначення ступеня готовності до сприйняття матеріалу тренінгу. Лекція-бесіда може перерости в лекцію-дискусію, яка передбачає активний обмін думками в інтервалах між логічним викладом матеріалу. Це, безперечно, пожвавлює тренінг, активізує пізнавальну діяльність учасників, дає можливість тренеру управляти колективною думкою групи. Щоб виник діалог, тренеру слід вступати в контакт 3 учасниками як співрозмовник, який хоче обмінятися своїми думками щодо проблеми тренінгу, власним баченням шляхів ііі розв'язання; визнавати право учасника на власний погляд щодо проблеми й бути зацікавленим в існуванні цієї думки. Також важливо доводити істинність нових знань не силою особистого авторитету, а шляхом обгрунтованих міркувань. Учасникам тренінгу слід надавати можливість ознайомитися 3 різними поглядами щодо проблеми, показувати iii розвиток і обгрунтовувати правильний шлях іiі розв'язання; шанобливо ставитись до думок учасників, створювати атмосферу співробітництва, невимушеності [3].

Доцільно також використовувати лекцію-аналіз конкретної ситуації, що нагадує лекцію-дискусію, тільки на обговорення тренер виносить не питання, а конкретну ситуацію. Це так звані мікроситуації, які демонструються аудиторії усно або у вигляді відеозапису тощо, іiі виклад має бути коротким, але суттєвим і змістовним, щоб його вистачило для всебічного обговорення. Учасники цю мікроситуацію аналізують всією групою. Тренер активізує цей діалог за допомогою спеціально спрямованих запитань, підказок, зіставленням різних поглядів, а іноді й їх зіткненням. Після цього він, спираючись на правильні та обгрунтовані відповіді, міркування і судження, аналізує цю ситуацію, надає переконливі докази щодо хибних думок й аргументовано підводить групу до колективного рішення чи висновку.

Під час проведення тренінгу одночасно зі словесними використовувати наочні методи та прийоми навчання. Серед наочних методів найчастіше застосовується метод показу.

Показ - це навчальний метод, що становить сукупність прийомів, дій і засобів, за допомогою яких створюється наочний образ предмета, котрий вивчається, формується конкретне уявлення про нього. Ефективність показу забезпечується дотриманням чіткого визначення мети i предмета показу; забезпеченням загального показу усіх елементів предмета, а потім повторення його окремих елементів 3 акцентуванням уваги на ключових моментах; відповідність способів показу змісту інформації, що висвітлюється.

Ефективним під час проведення тренінгу є показ тематичних науково-популярних фільмів або фрагментів художніх фільмів, що відображають проблематику тренінгу.

Суттєво допомагають закріпити і поглибити знання, отримані під час вступної частини тренінгу, актуалізації його проблематики та інформаційного блоку, імітаційні методи активізації навчальнопізнавальної діяльності учасників [2].

Основними різновидами ігрових імітаційних методів активізації навчально-пізнавальної діяльності, що пропонуються під час тренінгу $є$ методи інсценування і ділові ігри, метод аналізу конкретної ситуації.

Під час обговорення потрібно стежити, щоб не виникали діалоги або дискусії між окремими членами групи. Тренер повинен замикати на себе всі запитання і відповіді, підключаючи до обговорення всю групу. Під час керованого обговорення необхідно уникати дискусій. Дискусія в групі можлива лише за умови обмеження часу iii проведення та правильного добору запитань, вмілого і цілеспрямованого управління її ходом.

При проведенні тренінгу необхідно дотримуватись певних принципів його організації. Це, зокрема, мотиваційність, парадоксальність, образність, результативність. Важливим елементом концепції тренінгу є така його організація, за якої учасники отримують змогу на власному досвіді відчути парадоксальність механізму автономізації мотиву. Відомий принцип тренінгу - образність. Явища, які вивчаються і випробовуються в тренінгу, мають бути обов'язково відображеними в малюнках і схемах, метафорах і символах. Це допомагає не лише зрозуміти, засвоїти і запам'ятати, але й відчути внутрішню гармонію відкрити нове [4].

Також слід дотримуватись принципу тренінгу - баланс комфорту і дискомфорту. Суть його полягає в тому, що в цілому атмосфера в групі має бути комфортною, зручною, безпечною. Однак тактично, в окремі моменти тренінгу, в учасників повинен вникнути дискомфорт. Причинами його можуть стати неуспішні спроби вирішити завдання, виконати інструкцію, досягти позитивного результату будь-якого виду. Це можуть бути окремі труднощі, наприклад записувати щось в незручних умовах; писати лівою рукою; виконувати завдання в шумному приміщенні; звертатися з пропозицією до іншої 
команди, знаючи, що тебе чекає заздалегідь відмова та інші. Призначення всіх цих труднощів у тому, щоб допомогти учасникам відчути “великумотиваційну силудискомфорту”. Принцип тренінгу - спрямованість на застосування результатів - покликаний допомогти учасникам перенести отриманий досвід на практику. Тренінг повинен мати практичне значення.

Висновки. Отже, тренінг - це організаційна форма освітнього процесу в закладах вищої освіти, яка допомагає стати кожному учаснику групи більш компетентним; це процес, під час якого учасники вступають у взаємодію; процес, у центрі якого $є$ проблема та її розуміння учасниками групи, а не компетентність ведучого щодо зазначеної проблеми; навчання, під час якого активність учасників вища, ніж активність ведучого.

В процесі тренінгу здійснюється навчання, яке дає учасникам задоволення, активізує їх, стимулює інтерес до пізнання; результат якого досягається у взаємодії всіх учасників тренінгу. Важливе значення тренінгу полягає у відкритті учасниками в собі нових можливостей, відчуття того, що вони знають і вміють більше, ніж до цього часу думали про себе. Це також можливість відкриття інших людей, навчання через взаємодію 3 ними, розуміння того, на що здатні люди, від яких раніше не очікувалося нічого цікавого. Це можливість у безпечних, з одного боку, трохи штучних, а з іншого - наближених до реальності умовах взаємодії з іншими людьми досягти бажаних змін.

Перспективи подальших розвідок у даному напрямі. Перспективи подальших розвідок щодо використання тренінгових технологій у закладах вищої освіти ми вбачаємо у проектуванні системи роботи щодо їх використання в процесі практичних занять 3 професійно-орієнтованих дисциплін і т.п.

\section{ЛІТЕРАТУРА}

1. Закон України "Про вищу освіту" [Електронний ресурс]. Режим доступу http:// sfs.gov.ua/diyalnist-/zakonodavstvo-pro-diyalnis/ zakoni-ukraini/65715.html

2. Кузьмінський A.I. Педагогіка вищої школи: навч. посіб. / Київ: Знання, 2005. - 486 с.

3. Педагогіка вищої школи: навч. посібник. / За ред. 3.Н. Курлянд. Київ: Знання, 2007. - 495 с.

4. Шоробура I.M. Тренінги 3 освітнього менеджменту: навч. посіб./ Хмельницький: ФОП Мельник А.А., 2018.-242 с.

5. Шоробура I.M., Григор'єва А.А. Від творчого пошуку до педагогічних інновацій: навчальний посібник. / Хмельницький: Вид-во ХГПА, 2011. - 205 с.

\section{REFERENCES}

1. Zakon Ukrainy "Pro vyshchu osvitu" [Law of Ukraine "On Higher Education"]. [Electronic resource]. Available at: http://sfs.gov.ua/diyalnist-/ zakonodavstvo-pro-diyalnis/zakoni-ukraini/65715.html [in Ukrainian].

2. Kuzminskyi, A. I. (2005). Pedahohika vyshchoi shkoly: navch. posib. [High school pedagogy: tutorial]. Kyiv: Znannia, 486 p. [in Ukrainian].

3. Kurliand, Z.N. (Ed.). (2007). Pedahohika vyshchoi shkoly: navch. posibnyk. [High school pedagogy: tutorial]. Kyiv: Znannia, 495 p. [in Ukrainian].

4. Shorobura, I. M. (2018). Treninhy z osvitnoho menedzhmentu: navch. posib. [Trainings on Educational Management: a tutorial]. Khmelnytskyi: FOP Melnyk A.A., 242 p. [in Ukrainian].

5. Shorobura, I. M. \& Hryhorieva, A. A. (2011). Vid tvorchoho poshuku do pedahohichnykh innovatsii: navchalnyi posibnyk [From creative search to pedagogical innovations: tutorial]. Khmelnytskyi: Vyd-vo KhHPA, 205 p. [in Ukrainian].

Стаття надійшла до редакції 28.01.2019

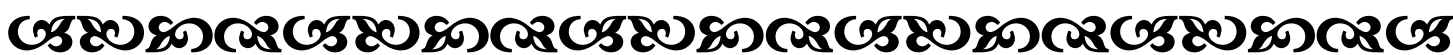

"Ми знаємо, хто миє, але не знаємо, ким ми можемо бути".

Вільям Нексnip англійський драматург

"Точніть робити те, що потрібно. Тотім робіть те, що можливо. І ви раптом виявите, що робите неможливе".

Святий

ФранцискАссізський

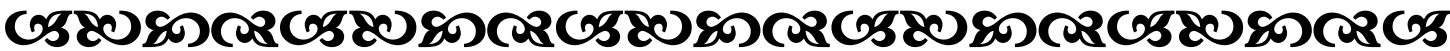

Молодь і ринок №2 (169), 2019 